\title{
Comparative Study and Experience of Government Accounting Reform in Developed Countries
}

\author{
Qingxiu Peng ${ }^{\mathrm{a}, *}$ and Lu Zhang ${ }^{\mathrm{b}}$ \\ School of Economics and Management, Zhengzhou University of Light Industry, Zhengzhou, China \\ apengqingxiu@163.com, ’949628148@qq.com \\ *Corresponding author
}

Keywords: Government accounting reform background, Reform process and content, Suggestion.

\begin{abstract}
This paper will describe the process and content of government accounting reform in developed countries in detail. And it will also put forward some suggestions based on the excellent experience of government accounting reform in developed countries and the dynamics of domestic economic development. At last it will give the most suitable countermeasures and development path for government accounting reform.
\end{abstract}

\section{Introduction}

Since the 1980s, the government's accounting information in China has not changed along with the continuous development of the social and economic environment. Compared with western developed countries whose government accounting reforms have been successively implemented, ours are in the initial stage, which is worth learning for our country. Focusing on the content of the government accounting reforms in the United States and the United Kingdom, this article will make an analyses and comparison with these two countries' reforms based on the China's overall national conditions so as to make relevant recommendations for the government accounting reform of our country.

\section{Background of China's Government Accounting Reform}

Since 1990, China's government accounting has gradually improved and established a budget accounting model based on the realization of collection and payment after a series of reforms. With the development of society and economic progress, the drawbacks of this type of budget accounting model have gradually emerged. First of all, under the general environment, the accrual accounting system is the basis of accounting in the international community. China's implementation of the payment and payment system cannot be achieved with international practice obviously. Second, the definition of the government accounting body in China is not clear enough, and there is not1 a relatively complete and unified government accounting system. With the continuous improvement of China's overall national strength, the quality of government accounting information also has higher requirements. The promulgation of "Government Accounting Standards - Basic Principles" officially opened the prelude to a new era of government accounting reform.

\section{The Process and Content of Government Accounting Reforms in Developed Countries}

\subsection{Comparison of Accounting Standards (norms)}

The U.S. is a federal state, and its accounting standards are constituted by the federal accounting standards, state and local government accounting standards. They were issued by the Federal Accounting Standards Advisory Committee (FASAB) and the Government Accounting Standards Advisory Committee (GASB). Although promulgated by different departments, they were all recognized by the American Institute of Certified Public Accountants (AICPA) and listed as General Accounting Principles (GAAP). 
The United Kingdom is a non-federal state that implements a constitutional monarchy. Although local government is affiliated with the central government, at the level of government accounting, the central government and local governments are independent. The British Ministry of Finance is in charge of the central government accounting and promulgates corresponding accounting standards. Local government accounting is subject to the accounting standards issued by the Chartered Institute of Public Accountants and Certified Public Accountants (CIPFA). Although the accounting regulations followed by the central government and the local governments are different, the two accounting standards are both based on the generally accepted accounting principles in the United Kingdom. Due to the need to compile the government's overall financial report, the two accounting specifications are becoming more and more similar.

\subsection{Comparison of Accounting Basis}

State and local governments in the United States use a large number of payment and realization systems in daily accounting. The statements of income and expenditure compiled for each ten-monthly and quarterly basis can be based on the accounting system for the realization of collection and payment. However, the financial reports prepared at the end of the year must be adjusted by using the accrual basis.

British government accounting is mostly based on the accrual accounting basis. The difference between the central government and the local government lies in the fact that the central government directly from the cash system to the full accrual system. Local government's gradual transition to the accrual system takes place gradually. As of now, the accrual accounting system is not only reflected in government accounting in the United Kingdom, but also uses the same accounting basis in the government budget. They believe that only the accounting basis of government accounting and budgeting can compare and analyze financial information and budget information and strengthen budget management.

\subsection{Definition of Government Accounting Subjects}

The United States defines the accounting entity according to the responsibility and resource allocation. The accounting entity can be either the entire government or the constituent unit. However, due to the existence of a large number of funds that are separately accounted for and reported, the United States has developed a "dual-subject" model in which accounting entities and reporting entities coexist. The "dual-subject" government accounting uses various funds as the basic unit for budgeting, financial management, and accounting. On this basis, government-level reports are provided to achieve the organic integration of micro-level fund accounting and macro-level government comprehensive annual financial statements.

The federal government and state and local governments have different accounting principal structures. In federal government accounting, each department has its own accounting system. And the government itself is a comprehensive reporting body. For the state and local governments, each department does not act as an accounting entity or a reporting entity. The government accounting is undertaken by a dedicated accounting department. From the perspective of the entire government, the fund is the main body for accounting treatment and reporting.

The accounting entities covered in the UK government's overall financial report include more than 1,300 public entities of various types in England, Scotland, Wales, and Northern Ireland. These entities can be divided into several categories: (1) Central government entities. (2) Local government public entities, including four regional councils which are fire services, local education authorities and schools. (3) Public enterprises, including state-owned industries, other public companies, trading funds, etc.

\subsection{Setting of Government Accounting Elements}

The US federal budget accounting system includes three elements: income, expenditure, budget surplus/deficit. The financial accounting system includes five elements: assets, liabilities, net assets, income, and expenses. State and local governments basically adopt the fund accounting model to reflect and supervise government financial activities and manage public resources. The accounting 
elements include assets, liabilities, and income, expenses, and fund balances.

British Government Accounting elements include assets, liabilities, equity, profits, losses, owner donation, and allocation to the owner.

\section{Enlightenment from the Reform of Government Accounting in Developed Countries in China}

Through the analysis of the environment and the status of the development of the accounting reforms in the United States and the United Kingdom, the following suggestions are made for advancing the accounting reform of the government in China.

\subsection{Promote Government Accounting Reforms Based on National Conditions}

The government accounting reforms of the United States, Britain and other developed countries are all based on their own unique social-economic environment. The basic trend of reform is to introduce the concept, principles, and methods of corporate accounting in government accounting. At the same time, practice innovation is combined with the actualities of the country and the characteristics of government accounting. The reforms also need to focus on regulating the specific business of the domestic government department. China's government accounting environment and the cultural background of entrusted responsibility are different from those of European countries and the United States. Therefore we have some recommendations on it: drawing lessons from the relevant contents of government accounting reforms in developed countries; pay attention to the similarities and differences between the domestic government accounting environment and the corporate accounting environment; combining the nature of the Chinese government and related departments, accounting standards, and the characteristics of business activities and other aspects have been improved so that the construction of the government accounting standards system conforms to China's national conditions.

\subsection{Scientifically Defining the Scope of Government Accounting Entities}

In the initial stage of government accounting reform, it is a great significance to scientifically to define the main body of government accounting and reporting, and to define the scope of government accounting reasonably. And then it formulates specific guidelines for government accounting and clarifies the accounting standards of government. At present, the selection model of foreign government accounting subjects mainly includes the two types which are "organization" subject and "fund" subject. Generally, they are defined according to the source of funds and the relationship of control. The practices of various countries are not completely consistent. It is suggested that the administrative agencies, institutions that do not implement enterprise management. Also agencies represented by government agencies should be included in the scope of government accounting and reporting entities, while state-owned enterprises should not be included in the scope of government accounting entities.

\subsection{Coordinate the Promotion of Accounting Reforms of Central and Local Governments}

Government accounting reform is a systematic project. The smooth implementation of the reform depends on the support of various departments. China is a unitary system of government and adopted a unified accounting system has for a long time. Therefore, there are many certain advantages on adopting the overall approach of the central and local governments to implement the reform of government accounting standards. It is recommended to learn from foreign experience to reduce resistance to change and to play a role in the reform of the administrative authority of the Ministry of Finance government accounting. At the same time, it should establish a relatively neutral government accounting standard-setting bodies to make all walks of life extensive exchanges and consensus-building platform. 


\section{Acknowledgments}

This research was financially supported by: 2017BJJ075; 2018-ZZJH-616; 182400410151.

\section{References}

[1] Ministry of Finance and Accounting, China Accounting Newspaper, Government Accounting Reform: Theory and Exploration, M. Beijing Economic Science Press.2015.

[2] Du Jinshuang, A Comparative Study of Chinese and American Government Accounting Systems, D. Dalian Maritime University.2015. 